\title{
One Health Approach of Melioidosis and Gastrointestinal Parasitic Infections from Macaca fascicularis to Human at Kosumpee Forest Park, Maha Sarakham, Thailand [Corrigendum]
}

Damrongsukij P, Doemlim P, Kusolsongkhrokul R, et al. Infect Drug Resist. 2021;14:2213-2223.

The authors have advised that the Acknowledgments section on page 2222 is incorrect. The acknowledgments should read as follows.

\section{Acknowledgments}

This research project was financially supported by Mahasarakham University (MSU). We would like to thank Professor Randall C Kyes and Dr Pensri Kyes, Departments of Psychology and Global Health, the Center for Global Field Study, and the Washington National Primate Research Center, University of Washington, Seattle, Washington, USA, Dr Penkhae Thamsenanupap, Faculty of Environment and Resource Studies MSU, and all the staff at Kosumpee Forest Park for their guidance and assistance in the field. We really feel thankful to Dr Panyupha Thammawat, Faculty of Humanities and Social
Sciences, Khon Kaen University for her valuable advice in the questionnaire design. We are grateful to Faculty of Veterinary Sciences, MSU for diagnostic laboratory and Wildlife hospital, Khon Kaen Zoo for melioidosis diagnostic laboratory. We also thank the Wildlife and Exotic Friends Club, MSU and students from Faculty of Environment and Resource Studies for the assistance with animal and human sampling. Finally, we are grateful to the Thailand Department of National Parks Wildlife and Plant Conservation (DNP), and the National Research Council of Thailand (NRCT project approval to RC Kyes - Project ID: 2016/048; "Healthy Coexistence between Human and Non-human Primates: A One Health Approach"). RC Kyes and $P$ Kyes' effort on this project was supported in part by the Office of Research Infrastructure Programs (ORIP) of the National Institutes of Health through Grant Number P51OD010425 to the WaNPRC.

The authors apologize for this error.

\section{Publish your work in this journal}

Infection and Drug Resistance is an international, peer-reviewed openaccess journal that focuses on the optimal treatment of infection (bacterial, fungal and viral) and the development and institution of preventive strategies to minimize the development and spread of resistance. The journal is specifically concerned with the epidemiology of antibiotic resistance and the mechanisms of resistance development and diffusion in both hospitals and the community. The manuscript management system is completely online and includes a very quick and fair peerreview system, which is all easy to use. Visit http://www.dovepress.com/ testimonials.php to read real quotes from published authors. 